\title{
The Exploring on the Current Situation and Ways of University History Education in the Era of New Media
}

\author{
Jieming Du ${ }^{1, *}$ Yuyang $\mathrm{Pan}^{2}$ and Ruixuan $\mathrm{Hu}^{3}$
}

\author{
${ }^{1}$ School of Management, Wuhan University of Technology, Wuhan, HuBei, China \\ ${ }^{2}$ School of Management, Wuhan University of Technology, Wuhan, HuBei, China \\ ${ }^{3}$ School of Management, Wuhan University of Technology, Wuhan, HuBei, China \\ *Corresponding author. Email:2971156332@qq.com
}

\begin{abstract}
The history of a university is a precious historical and cultural resource, and it is necessary and feasible to apply it to education activities, which is conducive to improving teachers and students' awareness of the school, and motivating teachers and students to strive for innovation. In the era of new media, school history education needs to use more methods to broaden education channels, enrich education content, expand education coverage, and ultimately promote the realization of the value of school history resources in education.
\end{abstract}

Keywords: New media, University history, Current situation, Approach

\section{INTRODUCTION}

The history of the university records the process of its creation, development and transformation, and records the efforts and contributions made by generations of builders to the progress and growth of the school. [1] The school history uses words, objects, photos, etc. to describe the major events, important decisions, advanced figures, advanced ideas and other things closely related to the development of the university from its inception to the present. This has an important guiding role in the construction of campus culture, the training and education of teachers and students, and the future development of colleges and universities. To a certain extent, the school history represents the spiritual and material wealth of the school. Through the school history, we can understand the wisdom of school development and guide the school on the right path.

With the development of digital technology, new media has developed rapidly by virtue of its advantages such as personalization and high interactivity with users, gradually breaking the traditional media propaganda model. [2] New media can provide massive information resources for college students, maintain real-time update speed and information interaction with users. It can play a huge role in school history and culture propaganda and cultural education. However, at present, in terms of publicity and education of university history, most universities have not formed a system for the publicity mode of new media. The publicity and education of school history are still using traditional newspapers and magazines, venue exhibitions, etc. Therefore, the effect of publicity and education is not ideal.

How to thoroughly study the spirit and culture contained in university history, and rationally use mediaintegrated communication methods, so as to give full play to the cultural education function of university history, cultivate the consciousness of college students to love the school, and let students learn and inherit the culture and spirit of the school spontaneously. This has become the next focus of the university history museum.

\section{PROBLEM EXISTING IN SCHOOL HISTORY EDUCATION}

At present, there are many problems in university history education, which leads to low education efficiency. According to our research, there are several main problems in university history education.

\subsection{The construction of the school history education team is weak}

The lack and weakness of the team is one of the reasons for the low efficiency and small coverage of school history education. Most universities only have a history research team and a teaching team. School history researchers and teachers are often two different groups 
and lack communication with each other. School history researchers only study school history only, which causes teachers to be unable to obtain school history research information in time and integrate school history into the curriculum. At present, many school history research teams lack comprehensive talents. [3] The team usually only has history and management talents, and lacks computer talents. This has led to the inability to integrate the results of school history education with new media in a timely manner, limiting the role of new media in publicizing school history.

\subsection{The utilization rate of school history resources is low}

Some newly-built colleges or merged universities do not pay enough attention to school history, and the research on school history is not deep enough. This results in the only school history research results that are very empty, fail to be transformed into effective teaching resources, and cannot be associated with ideological and political courses. In recent years, many universities have set a visit to the school history museum as the first lesson for students, but the actual effect is not satisfactory. The shortage of professional school history interpreters, short visit time, and shallow sense of loving the school make it difficult for students to understand the meticulous origins of school history, let alone feel the spirit of school history, and have minimal impact on students' subsequent university life.

\subsection{Online school history education channels have narrow coverage and low influence}

At present, the carrier of school history education in most universities is often limited to offline school history museums or highly professional school history lectures, and the way of education is monotonous and inefficient. Some universities that have established online school history museums have incomplete platform construction. Many simply upload some memorable photos or information about school history research, the update is slow or even stagnant, and the number of visitors is small. Universities with relatively complete platform construction have not carried out active publicity activities on the platform, which has caused the problem of low influence of the platform and serious disconnection from the student body.

\section{RESEARCH AND ANALYSIS}

In view of the current universal problems of university history education, through research, we obtain the real school history education programs and measures of each university, understand the current results of university history education and the degree of students' understanding of the school's history. Finally, we analyze the survey results to get a more acceptable school history education method.

\subsection{Questionnaire Approach}

According to the basic ways of propaganda and students' interest in school history, the questionnaire was made and put in. Effective questionnaires were recovered qualitative analysis and quantitative analysis.

According to the results of the questionnaire, some conclusions can be drawn. College students have high interest in school history. They believe that school history plays an important guiding role in improving personal quality, cultivating the sense of loving school and shaping the world outlook, outlook on life and values. However, the results show that students have a low degree of understanding of school history. Most students do not know how to obtain relevant information and knowledge about school history. The current publicity methods of school history cannot meet the needs of college students for understanding school history. College teachers rarely use school history for ideological and political education, and school history does not play its role in educating students well.

The results of the questionnaire mainly reveal the following three problems in the publicity and education of school history.

\subsubsection{The propaganda means of school history are insufficient}

The data results show that the main way of school history publicity at the present stage is to rely on the traditional WeChat platform, offline school history museum explanations and student conversations. These propaganda channels have narrow spreading scope and limited spreading content, and they cannot transmit school history to students in a more intuitive and vivid form. Students cannot learn about school history in a more convenient and efficient way, and will reduce their interest in school history to a certain extent. Students are highly interested in school history special exhibitions, online media publicity, school history-related competitions and practical activities, but at present the school has hardly used these channels for school history publicity. 


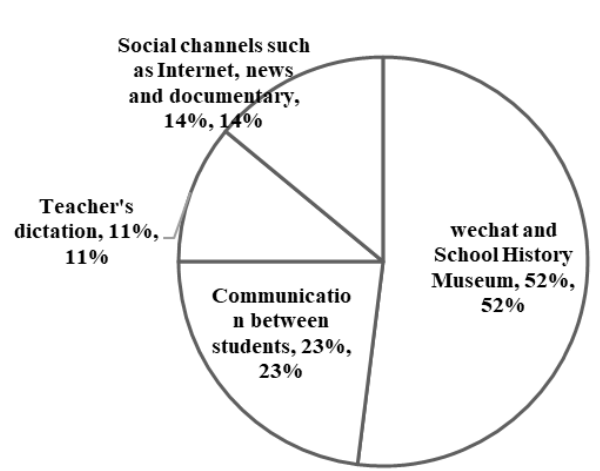

Figure 1 Channels for students to understand school history

\subsubsection{Teachers fail to integrate school history into students' Ideological and political education effectively}

The school history and its spiritual culture play an important role in the ideological and political education of students, but the school has not effectively used the school history in the ideological and political education of students. Teachers have a weak sense of using school history to teach. Most of the respondents have hardly received ideological and political education based on school history, which to a certain extent caused students' ignorance of school history and waste of school history education resources. [4]

\subsubsection{Inadequate use of the Internet in school history publicity}

Because of the growth environment, students have a high degree of acceptance of the Internet. This provides a new solution for school history publicity. However, according to the results of the questionnaire, the school's use of Internet methods in school history publicity is insufficient. School history publicity still uses traditional school history museum visits and WeChat public account publicity as the main publicity channels, which greatly limits the spread and depth of school history. How to apply Internet technology to school history publicity is the focus of school history publicity work.

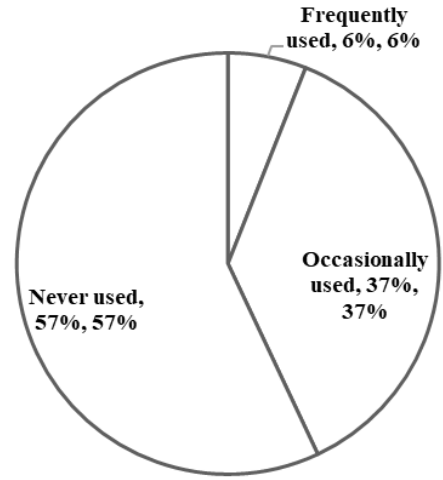

Figure 2 The extent of teachers' use of school history in Ideological and Political Education

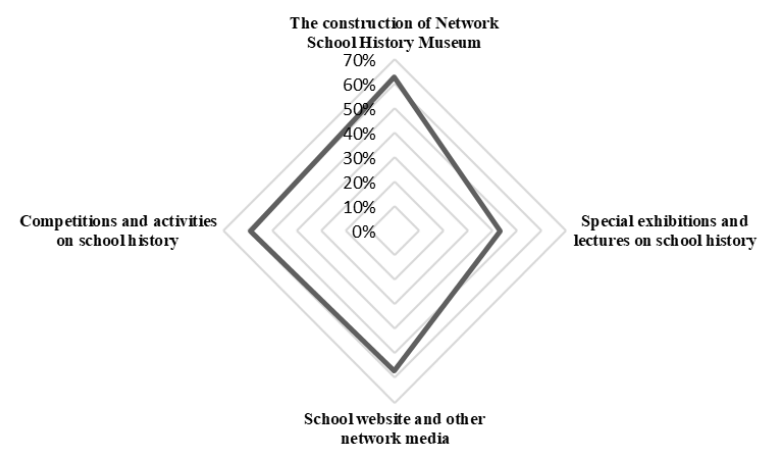

Figure 3 Lack of channels for school history publicity

\subsection{Case analysis Approach}

In order to understand the current status of school history education in various universities, a research team was established to conduct interviews and surveys with 52 universities. Mainly involved in the school history online and offline education construction and students' satisfaction with the school history education.

The survey involved 52 universities, including universities with a long history of establishment (13), universities established after the founding of the People's Republic of China (13), universities established after 2000 (13), and universities (13) merged to form universities.

Basically all universities have established offline school history education systems, and have successively launched offline hourly education. However, because of the limitations of offline school history education measures, student satisfaction needs to be improved. Compared with the online platform, the construction of the online school history education platform by universities is weak. The platform content management and update has not yet established a complete mechanism, and student satisfaction needs to be improved. 
Table 1. Feedback form for online and offline history education of universities

\begin{tabular}{|c|c|c|c|c|}
\hline Category & $\begin{array}{c}\text { School established } \\
\text { before the founding of } \\
\text { the country }\end{array}$ & $\begin{array}{c}\text { School established after } \\
\text { the founding of the } \\
\text { country }\end{array}$ & $\begin{array}{l}\text { School established after } \\
2000\end{array}$ & Merge to form a school \\
\hline $\begin{array}{l}\text { Conduct offline } \\
\text { school history } \\
\text { education }\end{array}$ & 13 & 13 & 13 & 13 \\
\hline $\begin{array}{l}\text { The satisfaction of } \\
\text { students with offline } \\
\text { school history } \\
\text { education }\end{array}$ & $\begin{array}{c}\text { Satisfied } 21.6 \% \\
\text { Basically satisfied } 51.3 \% \\
\text { Dissatisfied } 27.1 \%\end{array}$ & \begin{tabular}{|c|} 
Satisfied $26 \%$ \\
Basically satisfied $53.6 \%$ \\
Dissatisfied $20.4 \%$
\end{tabular} & $\begin{array}{c}\text { Satisfied } 24.9 \% \\
\text { Basically satisfied } 51.4 \% \\
\text { Dissatisfied } 23.7 \%\end{array}$ & $\begin{array}{c}\text { Satisfied } 27.1 \% \\
\text { Basically satisfied } 50.8 \% \\
\text { Dissatisfied } 22.1 \%\end{array}$ \\
\hline $\begin{array}{l}\text { Building an online } \\
\text { school history } \\
\text { education platform }\end{array}$ & 5 & 6 & 8 & 6 \\
\hline $\begin{array}{l}\text { The satisfaction of } \\
\text { students with online } \\
\text { school history } \\
\text { education }\end{array}$ & $\begin{array}{c}\text { Satisfied } 11.2 \% \\
\text { Basically satisfied } 46.4 \% \\
\text { Dissatisfied } 42.4 \%\end{array}$ & \begin{tabular}{|c|} 
Satisfied $13.6 \%$ \\
Basically satisfied $43.3 \%$ \\
Dissatisfied $43.1 \%$
\end{tabular} & $\begin{array}{c}\text { Satisfied } 15.3 \% \\
\text { Basically satisfied } 48.1 \% \\
\text { Dissatisfied } 37.6 \%\end{array}$ & $\begin{array}{c}\text { Satisfied } 12.5 \% \\
\text { Basically satisfied } 45.8 \% \\
\text { Dissatisfied } 41.7 \%\end{array}$ \\
\hline
\end{tabular}

\section{SUGGESTIONS FOR UNIVERSUTY HISTORY EDUCATION}

At present, there are many problems in university history education, which leads to low education efficiency. According to our research, there are several main problems in university history education.

\subsection{Formulate relevant system norms for school history education}

University history is an important part of college culture. In the era of new media, the education of school history and culture deeply integrated with "Internet +" has also become an important path for college education. University leaders should follow the trend and pay attention to it in a timely manner, formulate relevant policies based on actual conditions, actively introduce talents in the process of school history and culture construction, strengthen the construction of education teams, train relevant cultural construction teams and course teachers, and ensure financial support and improve the management system. In the construction of the platform, we pay attention to the mutual assistance and exchanges between the various platforms in the school, realize the sharing and intercommunication of university history and cultural resources and teaching resources, make full use of the school history resources to create a unique school history culture, and give play to the role of new media. In addition, universities must pay attention to the continuity of school history and culture research as the basic work of school history education, and should not limit the application of school history research results to the preparation of school celebrations and other related activities. Universities must support long-term research on school history and transform school history resources into effective teaching resources.

\subsection{Enrich the school history and culture education form}

Universities should strengthen exchanges between teachers and school history researchers, offer relevant public courses, support the integration of online and offline education, and deeply integrate school history culture into university ideological and political education classrooms. It is best for teachers to organize flexible and diverse forms of activities such as online answering questions, questionnaire surveys, knowledge activity contests, and online exhibitions to enrich the forms of school history education. At the same time, universities should also pay attention to enriching the forms of education and avoid being too entertaining.

\subsection{Create a good atmosphere in the school}

Universities should make extensive use of new media to promote the history of the school and stimulate the enthusiasm of teachers and students for school history and culture. At the same time, the school needs to establish a school history-related group, such as a cultural research group, an explanation group, and a performance group, to combine the interests and hobbies of teachers and students to give play to the educational role of school 
history and culture. [5] Encourage students to actively participate in related school history activities, cultivate students' sense of identity with school history and culture, and make students familiar with school history and culture in practical experience is also very important. The education function of school history not only relies on the classroom of ideological and political education, but also needs to be deeply integrated with other education activities of the school.

\section{CONCLUSION}

University history is a unique resource with rich educational content, which is conducive to better carrying out ideological and political education [6]. At the same time, how to use new media to enrich the content of school history dissemination, broaden dissemination channels, and expand the coverage of education is what every university needs to think about.

\section{PROJECT FUND}

This article is one of the phased achievements of the National innovation and entrepreneurship training program for college students+S202010497040 "Research on the Functions and Methods of University History and Culture Education in the New Media Era".

\section{REFERENCES}

[1] Qiu Yan, Miao Aiying. Research on the Integration of University History Resources and Cultural Education[J]. Journal of Anhui Agricultural University (Social Science Edition), 2019, 28(04): 134-140.

[2] Teng Fei. Research on the Function of University History and Culture Education and Its Realization Path [D]. Guangxi Normal University, 2018.

[3] Fu Chao, Wang rangxin, $\mathrm{Hu}$ Xin. Application of school history resources in Ideological and political education in Colleges and universities [J]. Party construction and ideological education in Colleges and universities, 2021 (02): 94-96

[4] Xia Huimin, Liu Yanhua. Analysis of the value of integrating school history and culture into Ideological and political education in Colleges and universities [J]. Modern communication, 2020 (23): 138-140

[5] Wu Jin, Luo Hui, Zhang Biao. The educational function of university history [J]. Journal of Mianyang Normal University, 2012,31 (06): 114118

[6] Niu Chunyu, Liu Liang. Analysis of the realization path of the ideological and political education function of school history and culture in the new situation[J].Journal of Henan University of Science and Technology,2018,38(08):48-51. 